\title{
A Comparison of Abstract Writing Style Between English and Chinese
}

\author{
Xiaoying Zhou ${ }^{1} \&$ Hangjie Liao ${ }^{2}$ \\ ${ }^{1}$ Foreign Language College, Nanchang Normal University, Nanchang, China \\ ${ }^{2}$ Purdue University, West Lafayette, USA \\ Correspondence: Xiaoying Zhou, Foreign Language College, Nanchang Normal University, Nanchang, Jiangxi \\ Province, 330032, China. Tel: 86-138-0709-7589. E-mail: thehundred2003@aliyun.com; 1365216679@qq.com
}

\author{
Received: December 19, 2017 Accepted: February 11, 2018 Online Published: February 13, 2018 \\ doi: $10.5539 /$ elt.v $11 \mathrm{n} 3 \mathrm{p} 18$ \\ URL: http://doi.org/10.5539/elt.v11n3p18
}

\begin{abstract}
In this paper the authors conducted a comprehensive study on English abstract writing style. Abstraction is the process of forming a theoretical concept based on the observation and classification of object things. This concept has no definite denotation. However in specific situation it can be clearly understood. In English, writing an abstract expression has always been a very important part. However, Chinese is a language which seldom uses abstract writing style. In this paper the authors will make a comparison between English and Chinese languages about the use of abstract writing style.
\end{abstract}

Keywords: abstract writing, abstraction, writing style, English, Chinese

\section{Introduction}

Abstract writing has always been a very important style in English language. With the development of society and human civilization more and more abstract terms come into use. And with the development of science and technology abstract style in English is frequently used not only in literary works, in scientific papers, even in daily communication. In English and American histories many famous writers, philosophers and politicians were very well grounded in using this abstract style and have left us many famous sayings in abstract style. The following are just some among many examples: "Survival of the fittest" (H. Spencer), "Beauty is truth, truth beauty." (Keats), "To be or not to be" (Shakespeare), "Studies serve for delight, for ornament and for ability" (Becon), "I marveled at the relentless determination of the rain" (N. Rigg), "This is the day for our two peoples to rise to the heights of greatness which can build a new and a better world." (R. Nixon) etc. Diachronistic linguistics study shows that the occurrence of abstraction symbolizes the fact that man has entered into a stage of abstract thinking. Actually the use of abstract style is closely related to the origin of language itself. Logical reasoning shows that in the course of human ideological thinking, language has experienced eight stages of development. Or, in other words, human language has covered eight important landmarks in its development. These eight stages are as follows:

1) The appearance of primitive verbs. It shows that human has entered into a stage from unconsciously reflecting the object world to the stage of consciously reflecting the object world;

2) The appearance of impersonal pronouns and demonstrative pronouns. This fact shows that human has entered into a stage of consciously analyzing and generalizing the world and began to form some concept of the object world;

3) The appearance of classification nouns and adjectives. It shows that man began to have a deeper understanding of the surrounding things;

4) The appearance of personal nouns. This phenomenon shows that human has deepened their understanding of human relations;

5) The appearance of prepositions. Man began to have a sense of time, space, aim, purpose, and cause and effect;

6) The occurrence of static sentences. It shows that human began to have a powerful tool for judgment;

7) The appearance of conjunctions. Man began to have a powerful tool for reasoning and they have deepened their sense of such logical concepts as cause and effect, conditions etc; 
8) The appearance of the abstract noun. It symbolizes the fact that human has entered into the stage of abstract thinking, the ultimate stage of human thinking.

When man entered into the stage of abstract thinking, he began to look at the object world from an abstractive way. At this stage, grammar itself is not only a way to describe the object world, but also a way to express man's subject world as well. When a man stands in front of a beautiful lake with a light preen mountain background, instead of saying "What a beautiful lake!" He may say: "I am so marveled art the natural beauty of the lake!" to express his state of mind at that moment. Actually, many famous writers like to express their feelings in this way. And on the contrary some unnecessary specific terms are gradually disappearing. As compared with English language, Chinese is a language which seldom uses abstract writing style. Abstraction is the process of forming a theoretical concept based on the observation and classification of object things. In some uncivilized nations such words "white cow"; "red cow"; "wattle-tree" and "gum-tree" are used, however the words as "tree" and "cow" are seldom seen. In modern information age, the use of abstract expressions is not reduced but increased. In English and American histories, many famous writer, philosophers and politicians were very well grounded in using this abstract style and have left us many famous sayings in abstract style, such as the following sentence from (The Atlantic Charter): "The joint expression of aims common to the United States and the British commonwealth of Nations known as the Atlantic charter includes not only purposes covering war but outlines of more distant objectives".

We can clearly see in the above example that the use of abstract expressions is closely related to the development of society. The occurrence of abstraction symbolizes the fact that the writer and the readers have entered a stage of abstract thinking. At this stage, grammar itself is not only a way to describe the objective world, but also a way to express a person's subjective world as well. If all the abstract expressions in the above example are withdrawn, then these writings would become meaningless. In another example, from article "Crime" in an American newspaper: "Newspapers devote a large amount of space to crime news. The chief source of crime news is the city police, which generally enforce laws on murder, robbery, larceny and other crimes". In above there includes a lot of abstract expressions, which play a very important role in the transmitting of meaning. The words as murder, robbery, larceny and other crimes represent the meaning of the whole passage. Without these abstract expressions the whole passage would become completely meaningless. Many famous writers like to express their feelings in this way. Psychological theory holds that in the course of knowing the object world, a person not only needs to know the phenomenon of the things around but, more importantly, to know the essence and the law of the object world, too. During this process, concepts play a very important role. Inspiration originates itself from the concepts and concepts, in turn, are expressed with words. Generally speaking, the founding of all systems of scientific theories is based on concepts. So far as geometry is concerned, its basic starting point is axiom, on which a series of deductive reasoning is done. In literary works, their basic units are concepts expressed in words. With these words the literary writers left us many famous works.

\section{A Comparison of Abstract Writing Style between English and Chinese with Some Literary Examples}

As compared with English language, Chinese is a language which seldom uses abstract writing style. For example in Confucius “Great Learning” there are “大学之道, 在明明德, 在亲民, 在止于至善。知止而后有 定, 定而后能静, 静而后能安, 安而后能虑, 虑而后能得。物有本末, 事有终始, 知所先后, 则近 道矣。古之欲明明德于天下者, 先治其国者, 先齐其家; 欲齐其家者, 先修其身; 欲修其身者, 先正其 心; 欲正其心者, 先诚其意; 欲诚其意者, 先致其知; 致知在格物。格物而后至, 知至而后意诚, 意诚 而后心正，心正而后身修，身修而后家齐，家齐而后国治，国治而后天下平。自天子以至庶人，壹是皆 以修身为本。起本乱而末治者否矣。其所厚者薄, 而其所薄者厚, 未之有也”。一大学。 (Confucius) We can not find many abstract nouns as the passage quoted. This is not only because the writer did not like abstract writing style, but also because Chinese language itself restricted the use of such writing style.

As language is a phenomenon related to human psychology, any language change must also be connected with the psychological state of man who uses the language. We all know the proverb "A friend in need is a friend indeed". The word "friendship" bears much more information than the noun "friend". However, if we say "Timely friendship can test true friends" would be much better than the former proverb. Abstract nouns have more semantic coverage than common nouns. Some abstract nouns possess vary deep meaning. These abstract nouns, in their specific situations, play a fairly important role. This is the most important rhetoric role abstract nouns play in writing, especially in literary works. It can be said with certainty that without abstract nouns the beautiful meanings conveyed here would be damaged or become literally meaningless. This is the very function abstract nouns can play, impossible to any other nouns or expressions. Take W. Shakespeare's Sonnets as examples, we can find many such expressions. With these abstract expressions he can not only express his moving sentiments, but also give us a deep insight of the things he describes. The following are some examples: 
"If the dull substance of my flesh were thought, Injurous distance should not stop my way; For, then, despite of space, I would be brought, From limits far remote, where thou dost stay". (Sonnet 44); "Some say thy fault is youth, some wantonness, some say thy grace is youth and gentle sport; Both grace and faults graces that to thee resort. Thou mak'st faults graces that to thee resort." (Sonnet 96); "Those pretty wrongs that liberty commits, When I am sometimes absent from thy heart, Thy beauty and thy years full well befits, For still temptation follows where thou art." (Sonnet 41); "Look in your glass, and there appears a face that overgoes my blunt invention quite, Dulling my lines, and doing me disgrace." (Sonnet 103); "If some suspect of ill masked not you show, Then thou alone kingdoms of heart shouldst owe." (Sonnet 70); "Kind is my love today, tomorrow kind, Still constant in a wondrous excellence." (Sonnet 103); "If thy unworthiness raised love in me, More worthy to be belov'd of thee." (Sonnet 150); "O! call not me to justify the wrong, That thy unkindness lays upon my heart." (Sonnet 139) In all the above poem lines abstract expressions play a very important role. It can be said with certainty that without abstract expressions there would be no Shakespeare's Sonnets.

\subsection{The Factors Concerning the Use of Abstract Writing Style}

\section{(a) Social factor}

With the development of society and human civilization, more and more abstract terms come into use. For example: "The tradition of cultural pessimism can itself impede the search for solution. ... Indeed, some thoughtful Europeans would like to see the Continent's difficulties grow sharper in order to raise public consciousness --- and stimulate public pressure for solutions". (The Decline of Europe); "Behind that paradox is a recognition by Reagan and other politicians that public confidence in big government has skidded sharply over the last two decades. Not only was Reagan elected in 1980 on an anti-Washington theme, but he also used it to achieve unprecedented cuts in taxes and the size of domestic government agencies" (Government Under Fire); "It is my intention to curb the size and influence of the Federal establishment and to demand recognition of the distinction between the powers granted to the Federal government and those reserved to the states or to the people. All of us need to be reminded that the Federal government did not create the states, the states created the Federal government." (R. Reagan: Inaugural address); "The business of our nation goes forward. These United States are confronted with an economic affliction of great proportions. We suffer from the longest and one of the worst sustained inflation in our national history. It distorts our economic decisions, penalizes thrift and crushes the struggling young and the fixed-income elderly adult, threatens to smash the lives of millions of our people." (R. Reagan: Inaugural address); and "As Secretary of State George P. Shultz asserted Monday, the political support that Mr. Reagan won for his nuclesar stance toward the Soviet Union is important both as a signal to Moscow of Western firmness and cohesion and also as a demonstration to the people of Western firmness and cohesion and also as a demonstration to the people of Western nations that the diverse leaders who came here stand together" (For Reagan, Williamsburg Was a Political Smash--- but an Economic Fizzle). We can see clearly see that the use of abstract expressions is closely related to the development of society.

\section{(b) Psychological factor}

As language is also a phenomenon related to human psychology, any language change must also relate to the psychological state of the person who uses the language. The use of abstract expressions in writing can be subdivided into following points: 1 : Some scholars hold that as the abstract thinking is a kind of superior mind and a mark of civilized man, with the progress of social civilization and the advance of science and technology. 2: The meaning of abstract expressions is rather indistinct, therefore it can be used to cover up the author's cloudy or true state of mind for some purpose. 3: Some scholars hold that abstract writing is rather easy and simple in their grammatical structure as compared with other writing style. For example: “John's carelessness resulted in his failure in the examination". So far as grammar is concerned the sentence is fairly simple in the grammatical structure. "As John is careless he failed in his examination". "John failed in his examination because he is careless". The sentences are all compound complete sentences. They are grammatically complicated in the structure. Psychological theory tells us that most readers like to read sentences which are simple in their grammatical structure and with more information implied. "His carelessness caused his failure in the examination". "His carelessness resulted in his failure in the examination". "His carelessness is the cause of his failure in the examination". As can be seen from above mentioned examples, the sentences at least three abstract nouns are used.

\section{(c) Linguistic factor}

This is the third factor, which influences the use of abstract writing style. In English language, there are many word affix (both prefix and suffix) of abstract nouns in English language. There are a lot of English abstract nouns with Latin origins. Therefore, many such nouns are widely used in English language. For example: "For 
most Americans, irrespective of party affiliation and predisposition, isolationism is defunct and participation and cooperation commonsense and essential, in international relations". "Merely to enumerate these five outstanding characteristics of an urban community, namely, chaotic stimulation, and complexity of organization, suggests many implications for the city education". The above are two examples with such abstract nouns.

The above three factors are generally regarded as chief factors affecting the use of abstract writing style in English language. Among these three factors, the most important one is the one lying in the language itself. All the other factors are the secondary compared with this one.

\subsection{In Chinese the Writers Often Like to Use Concrete Things to Express Their Abstract Feelings}

In Chinese cultural tradition, literary writers often like to place their feelings on object things. For example, in $\mathrm{Li}$ Bai's “The Yo-Mei Mounta in Moon” almost no abstract noun is used: “峨嵋山月半轮秋，影入平㒸江水流。 夜发清溪向三峡, 思君不见下渝州”。In Chinese the writers often like to use concrete things to express their abstract feelings. The most commonly used objects are wind, flowers, snow and the moon, especially in poems. Li Bai in his famous poem "Night Thoughts" placed his nostalgic sentiment on the mountain moon. Many classical poems use moon as their topic. There is not enough affix to express the abstract meanings. The fact is there are only a small number of such abstract nouns there. In order to show the contrast let's quote a passage from Laotzu's “The Classic of the Virtue of the Tao”: “江海之所以能为百谷王者, 以其善下之，故能为百 谷王。是以圣人欲上民, 必以言下之; 欲先民, 必以身后之。是以圣人处上而民不重, 处前而民不害。 是以天下乐推而不厌。以其不争, 故天下莫能与之争” (第 66 章)。 It is quite clear that in Chinese language there are no abstract nouns. Even in Laotzr's very famous classics we can not find many such abstract nouns. But, instead, there are many specific nouns as mountains, rivers the sun and the moon and even grasses. Even the popular Chinese affixes like “性”, “化”, “度”, “主义” are nothing but borrowed from English.

Real abstract writing style means that in a piece of writing there are some real abstract nouns used. For example: "The exact terms of the normalization remain to be worked out". The things these nouns represent are real, but they are abstract in meaning. "Reading a novel takes much time", "He borrowed a dictionary from the library yesterday". In the examples all the nouns are real specific nouns. Real specific writing style refers to the writing which included real specific nouns. This is the most commonly used writing types.

Imaginary abstract writing style refers to the type of writing which contains unreal abstract nouns. For example: "It is believed that some Buddha images possess spirituality". The thing the nouns represent can not be found in the real world. "Imagination is regarded as the window of one's soul", "Paradise is the place where God lives". Imaginary specific writing style refers to the writing type contain some unreal specific nouns, such as hell, devil, paradise, dragons. All the nouns, either real or imaginary, are abstract in meaning. The word "soul" is regarded as an imaginary abstract noun, because it does not exist in the material world. However, the word "friendship" is a real abstract noun, because it can not be seen or physically felt, but it does exist among the people.

\subsection{Some rhetoric Functions of Abstraction in English}

In English Language abstract writing style possesses many rhetoric functions. The writer can use English abstract writing style to cover up his cloudy ideas or for some other purposes. It is just because abstract writing style possesses such features that some writers tend to use it rather abusively, resulting in their meanings rather ambiguous and even hard to understand. It is just like a beautiful scene covered in a thick mist, making the travelers hard to have a clear view of its true nature. From the point of aesthetics this is a beauty of distance. For it can give the reader a beauty of dim sense. But if it is used rather abusively, then its rhetoric functions will show a negative effect. Although being meaning it will not bear any sense. For the readers may find it boring to read such writings and may discard it in the end. For example: "Nature has no kindness, no hospitality, during a rain. In the fieriest heat of sunny days, she retains a secret mercy, and welcomes the wayfarer to shady hooks of the words whither the sun cannot penetrate; but she provides no shelter against her storms." (Nathaniel Hawthrone "The Old Manse").

Abstract nouns have more semantic coverage than common nouns. This is the most important rhetoric role abstract nouns play in writing, especially in literary works, because the use of abstract nouns can express the writers' comprehensive thoughts. This is the very function abstract nouns can play, impossible to any other nouns or expressions. For example: "The river sleeps along its course and dreams of the sky and of the clustering foliage, amid which fall showers of broken sunlight, imparting specks of vivid cheerfulness, in contrast with the quiet depth of the prevailing tint. Of all this scene, the slumbering river has a dream picture in its bosom." (Nathaniel Hawthrone "The Old Manse").

The use of abstract nouns can convey very deep meaning. As abstract thinking is by far the most advanced 
thinking pattern of mankind, the use of abstract writing style is also a very superior one. Here abstract nouns play a very essential role. For example: "All the sky glows downward at our foot; the rich clouds float through the unruffled boson of the stream like heavenly thoughts through a peaceful heart" (Nathaniel Hawthrone "The Old Manse"). The example contains very deep and vivid meaning, which is quite beyond words to describe. This is the secret abstract nouns can play in writing. "Nature has no hospitality" is another very good example to show the magic role of abstract nouns. If it is not used we may use many long sentenced to describe comprehend, once correctly used it can create wonders. However, just like a wind, if not correctly used, it may damage our writings. This is the very problem in using abstract writing style in English language.

\subsection{Four Types of the Abstract Writing Style}

(a) Real Specific Writing Style

Real specific writing style refers to the writing which includes real specific nouns. This is the most commonly used writing types. In our daily life a great number of writings we see belong to such writing style. For example: "Reading a novel takes much time", "He borrowed a dictionary from the library yesterday", "He took a picture with his newly bought camera". In the above examples all the nouns are real specific nouns.

(b) Real Abstract Writing Style

Real abstract writing style means that in a piece of writing there are some real abstract nouns used. The things these nouns represent are real, but they are abstract in meaning. For example: "The exact terms of the normalization remain to be worked out", "His appointment last week was interrupted as the President's olive branch extended to labor", "Is the emigration of intelligence to become an issue as absorbing the immigration of strong muscle?". The above examples can illustrate this problem.

(c) Imaginary Abstract Writing Style

Imaginary abstract writing style refers to that type of writing which contains unreal abstract nouns. In other words, all the things the nouns here represent can not be found in the real world. For example: "Imagination is regarded as the window of one's soul", "It is believed that some Buddha images possess spirituality". We take the above examples to show the feature of this writing style.

(d) Imaginary Specific Writing Style

Imagination specific writing style refers to the writing type which contain some unreal specific nouns, for examples: hell, devil, paradise, dragon etc. For example: "According to Buddha doctrine after their death some people will go down to the Hell for the sins they have committed in this world." "Dragon is regarded as the symbol of Chinese emperor". "Paradise is the place where God lives"

\section{Summary}

In all the above examples all the nouns, either real or imaginary, are abstract in meaning. For example, "friendship" is a real abstract noun, because it can not be seen or physically felt, but it does exist among the people. However the word "soul" is regarded as an imaginary abstract noun, because it does exist in the material world. What we discuss here is just thee two types of writings. Abstraction is the process of forming a theoretical concept based on the observation and classification of object things. With the development of science and technology abstract style in English is frequently used not only in literary works, in daily communication and in scientific papers. For example: "Survival of the fittest" (H. Spencer). The use of abstract style is closely related to the origin of language itself. When a person entered into the stage of abstract thinking, he/she began to look at the object world from an abstractive way. For example, when a man stands in front of a beautiful lake with a light green mountain background, he may say: "I am so marveled at the natural beauty of the lake!" to express his state of mind at that moment. Open up any literary works or philosophical classic we can often find streams of abstract expressions. For example: "The love is better than high birth to me, Richer than wealth, prouder than garments' lost." (Shakespeare's Sonnet 91). It can be said with certainty that without abstract expressions there would be no Shakespeare's Sonnets. As the readers can find many examples about abstract writings, the authors will not further discuss it in detail.

\section{References}

Alber, J., \& Fludernic, M. (eds.). (2010). Postclassical Narratology: Approaches and Analysis. Columbus: The Ohio State University Press.

Bhabha, H. (1994). The Location of Culture. London \& New York: Routledge.

Chen, J. (1994). How to Teach Chinese Students to Write Good English. Beijing: Foreign Language Teaching and 
Research.

Chierchia, G. (2013). Logic in Grammar: Polarity, Free Choice, and Intervention. Oxford: Oxford University Press. https://doi.org/10.1093/acprof:oso/9780199697977.001.0001

De Souza. L. (2010). Interlingual Re - instantiation: A Model for a New and Comprehensive Systemic Functional Perspective on Translation. Florianopolis: University Federal de Santa Catarina.

Garcia-Carpintero, M., \& Koelbel, M. (2008). Relative Truth. Oxford: Oxford University Press. https://doi.org/10.1093/acprof:oso/9780199234950.001.0001

Heiden, B. (2014). Narrative in poetry: A problem of narrative theory. Narrative, 2, 269-283. https://doi.org/10.1353/nar.2014.0015

Katan, D. (2008). Translating Cultures: An Introduction for Translators, Interpreters and Mediators. Shanghai: Shanghai Foreign Language Education Press.

Kjerkegaard, S. (2014). In the waiting room: Narrative in the autobiographical lyric poem, or beginning to think about lyric poetry with narratology. Narrative, 2, 185-202. https://doi.org/10.1353/nar.2014.0008

Li, W. (1993). China English and Chinglish. Beijing: Foreign Language Teaching and Research.

Li, Z. (1992). Newspaper English. Beijing: The Foreign Language Teaching \& Research Press.

Lian, S. (1993). A Contrastive Study of the Methods of Diction: English Abstractness Vs. Chinese Abstractness. Harbin: Foreign Language Research.

Liu, Z. (1982). Five Lectures on Chinese Poetry. Beijing: The Foreign Language Teaching \& Research Press.

Recanati, F. (2012). Contextualism: Some varieties. In K. Jaszczolt (Ed.), The Cambridge Handbook of Pragmatics. Cambridge: Cambridge University Press. https://doi.org/10.1017/CBO9781139022453.008

Sennet, A. (2011). Unarticulated constituents and propositional structure. Mind \& Language, 4, 412-435. https://doi.org/10.1111/j.1468-0017.2011.01423.x

Sheffield Hallam University. (2016). Longitudinal evaluation of the mathematics teacher exchange: China-English --- Interim research report. London: DfE, Annex 1: iv.

Stanley, J. (2002). Making it articulated. Mind and Language, 1, 149-168. https://doi.org/10.1111/1468-0017.00193

Tao, B. (1981). An outline of the Theory of Inspiration. Shenyang: Liaoning People's Publishing House.

Weaver, A. (2014). Toward a narratological analysis of The Romantic Lied: Event, voice and focalization in nineteen-century German poetry and music. Music \& Letter, 3, 374-403. https://doi.org/10.1093/ml/gcu068

Xia, J. (1976). A Collection of American Essay. Hong Kong: World Today Press.

Xiaoyan, L., Huma, K., \& Minxuan, Z. (2016). How Shanghai does it: insights and lessons from the highest-ranking education system in the world. Washington: World Bank Group.

Yang, Z. (2015). Subjectivity in translation as interlingual re - instantiation. Journal of World Languages, 1, 18-31. https://doi.org/10.1080/21698252.2015.1010249

Zhang, J. (1981). An Outline of Comparative Grammar between English and Chinese. Beijing: Commercial Press.

\section{Copyrights}

Copyright for this article is retained by the author(s), with first publication rights granted to the journal.

This is an open-access article distributed under the terms and conditions of the Creative Commons Attribution license (http://creativecommons.org/licenses/by/4.0/). 